\title{
Construction of evaluation system and evaluation model of urban environmental engineering geological problems — a case study of Jinan City
}

\author{
Yunfeng Zhang ${ }^{1,2}$, Ana $\mathrm{Wu}^{3}$, Jianjun Shen ${ }^{4}$, and Qing Cao ${ }^{4 *}$ \\ ${ }^{1}$ Shandong Provincial Geo-mineral Engineering Exploration Instiute, Jinan ,250014, China \\ ${ }^{2}$ Shandong Fifth Institute of Geology and Mineral Exploration, Taian, 250013, China \\ ${ }^{3}$ Shandong GEO-Surveying \& Mapping Institute, Jinan, 250002, China \\ ${ }^{4}$ College of Chemical Engineering and Safety, Binzhou University, Binzhou, 256600, China.
}

\begin{abstract}
In order to further study the problems of urban engineering geological environment, taking Jinan as an example, the environmental engineering geological problems are divided into four aspects: primary environmental engineering geological problems, secondary environmental engineering geological problems, the influence of human activities and the restriction of spring water on engineering construction. A multi-level, multi-objective and multi factor evaluation index system suitable for environmental engineering geology is established. The mathematical model is established by using analytic hierarchy process and fuzzy comprehensive evaluation method to evaluate the primary environmental engineering geological problems, secondary environmental engineering geological problems, the impact of human activities and the restrictive effect of spring water on engineering construction. The mathematical model is established by using Nemero index method to comprehensively evaluate the environmental engineering geological problems in Jinan, and the suitability zoning of engineering construction is carried out.
\end{abstract}

\section{Introduction}

Environmental engineering geology is a new discipline. Artificial and natural environments jointly shape cities, and urban construction and geological environment promote and restrict each other [1]. Therefore, in urban engineering geology, it is necessary to predict all types of geological engineering problems in cities and suggest corresponding prevention and control strategies [2].

The study of urban engineering geological environment in the modern sense began in the late 1960s when engineering geology in urban planning was gradually realised in practice. With the acceleration of urbanisation and rapid development of economic construction in China, in mining engineering, water conservancy and hydropower, urban construction, geological disasters, water and soil pollution, and other aspects of

*Correspongding author: caoqing526@163.com 
environmental engineering geology have carried out a series of research, and achieved a lot of research results. Human engineering activities have accelerated the transformation of the natural geological environment, which has become a driving force keeping pace with natural action. In addition, in big cities with dense populations and frequent economic activities, the consequences are often quite serious once geological disasters or environmental accidents occur. They cause great economic losses and social impact, even causing local social instability [3-6]. Therefore, the study of modern urban environmental engineering geology has essential theoretical and practical significance for correctly understanding the law of environmental engineering geology, revealing, reducing, and avoiding the environmental engineering geology problems, and improving the environmental quality of urban engineering geology.

Taking Jinan city as an example, this paper summarizes the environmental engineering geology problems into four aspects: primary environmental engineering geology problems, secondary environmental engineering geology problems, the effect of human activities and the restriction of spring water on engineering construction. A multi - level, multi - objective and multi - factor evaluation index system suitable for environmental engineering geology is established. The factors affecting environmental engineering geology are quantitatively analyzed and evaluated by analytic hierarchy process(AHP) and fuzzy comprehensive evaluation method. The safety of environmental engineering geological problems in Jinan city is divided into districts.

\section{Main contents of urban environmental engineering geology research}

With the development of society, the impact of human activities on the engineering geological environment has become increasingly evident, and the environmental engineering geological problems caused by this have become increasingly severe and complex [7-18].

(1) Traditional regional engineering geology problems: It includes soft soil, expansive soil, collapsible loess, liquefied sand, and other special soils, as well as deformation failure of deep and large foundation pits.

(2) Geological disasters: It includes collapse, landslide, debris flow, ground subsidence, ground collapse, ground cracks, and geological disasters caused by mine development.

(3) Seismic geology includes crustal stability and tectonic earthquakes formed by active faults.

(4) Geological problems formed by human engineering economic activities: It includes mine tailings pond, garbage storage yard, artificial water storage reservoir, underground space development, and groundwater overexploitation.

(5) Geochemical and environmental problems include water and soil pollution and heavy metal pollution.

(6) Issues related to land governance: It includes soil erosion and land desertification.

\section{Evaluation Methods of urban environmental engineering geology}

At present, foreign countries have combined sustainable urban development with engineering geology, and the study of engineering geology has leapt from quantitative change to qualitative change [19-25].

With the development of the economy, standardisation of the construction industry, and gradual attention to engineering geology, urban engineering geology developed into a 
specialised discipline [26-36]. Miao selected the grey clustering evaluation model and fuzzy comprehensive evaluation model, adopted the priority relation ranking method and principal component analysis method to screen and optimise each evaluation index, and conducted comprehensive analysis and evaluation on the geological environment quality [37-39].

This paper used analytic hierarchy process (AHP) and fuzzy combined evaluation method to establish a mathematical model to evaluate the primary environmental engineering geology problems, secondary environmental engineering geology problems, the impact of human activities, and the restricting effect of spring water on engineering construction. Nemerow index method was used to establish a mathematical model to comprehensively evaluate the environmental engineering geological problems in Jinan city, and to partition the engineering construction suitability. The evaluation model is shown in Figure 1. The index classification of karst collapse evaluation is shown in Table 1.

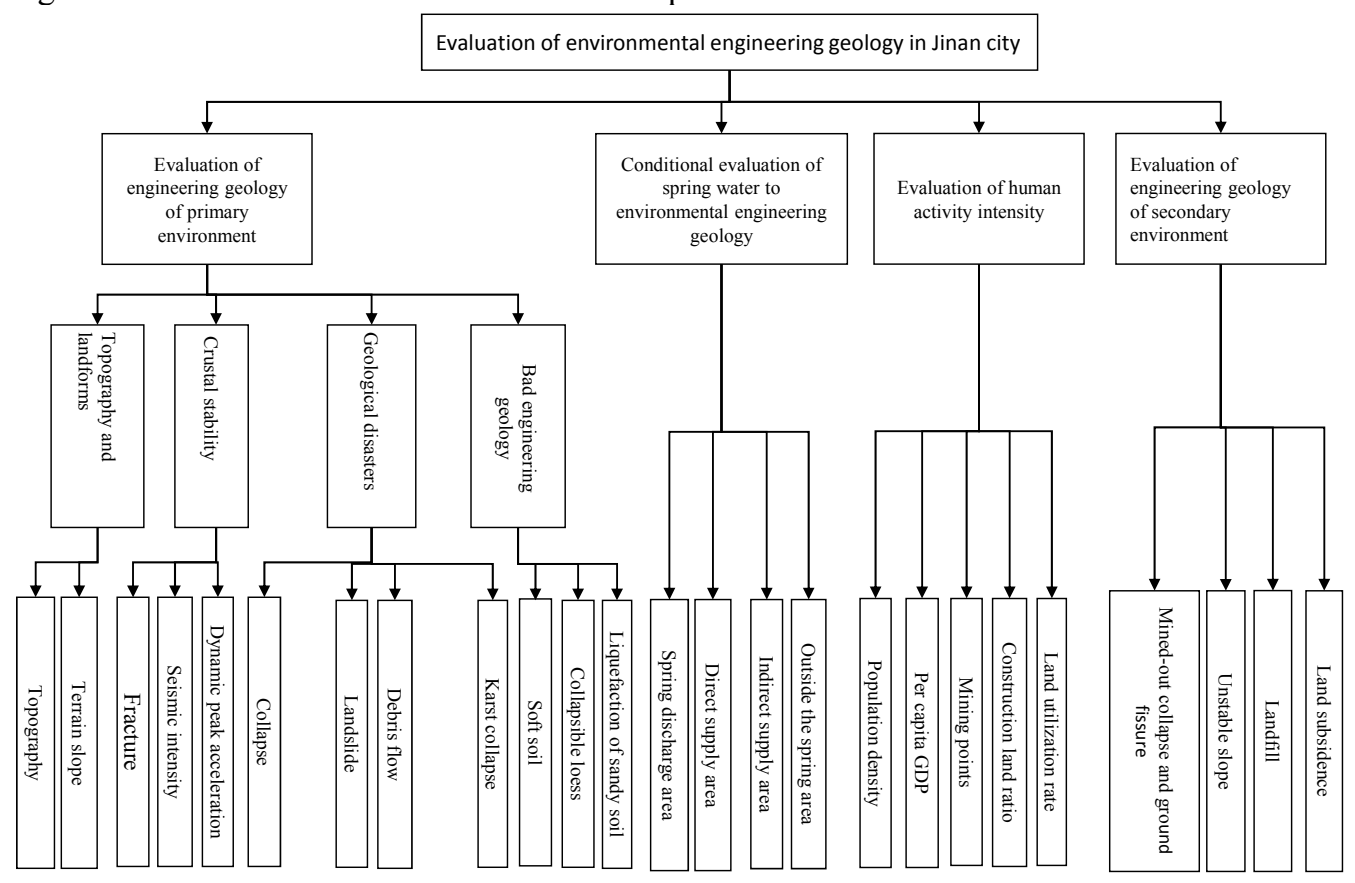

Fig. 1. Evaluation system.

Using the grid division function of the MAPGIS software, the city's grids were named from 1 to 2029 according to the User ID, and a total of 2029 grids are divided. The factors affecting major environmental engineering geological issues are primary environmental engineering geological factors and secondary environmental engineering geological factors. Because the primary environmental engineering geological problems and the secondary environmental engineering geological problems are complementary in affecting the major environmental engineering geological problems of Jinan, the Nemerow index method and the analytic hierarchy process are combined to comprehensively evaluate the two secondary indicators. The results are shown in Figure 2 and Figure 3.

Table 1. Hierarchical classification table of karst collapse evaluation indexes.

\begin{tabular}{cccc}
\hline Factors of grade four & Factors of grade five & Factors of grade six & Risk level \\
\hline \multirow{2}{*}{ Karst collapse $\mathrm{D}_{4}$} & Bedrock lithology E13 & Dominated by limestone & I High risk \\
& & Mixture of limestone and sandstone & Il Risk \\
\hline
\end{tabular}




$\begin{array}{ccc} & \begin{array}{c}\text { Dominated by sandstone } \\ \text { Dominated by siltstone }\end{array} & \text { III Less risk } \\ \text { Stronger } & \text { IV Small risk } \\ \text { Karst development } & \text { Strong } & \text { I High risk } \\ \text { degree E14 } & \text { Ordinary } & \text { II Risk } \\ & \text { Weak } & \text { III Less risk } \\ & 0-30 & \text { IV Small risk } \\ \text { Overburden } & 30-50 & \text { I High risk } \\ \text { thickness(m)E15 } & 50-70 & \text { II Risk } \\ & >70 & \text { III Less risk } \\ & 0-15 & \text { IV Small risk } \\ \text { Groundwater } & 15-30 & \text { I High risk } \\ \text { depth(m)E16 } & 30-45 & \text { II Risk } \\ & >45 & \text { III Less risk } \\ & \text { IV Small risk }\end{array}$

Figure 2 shows the risk assessment results of engineering geological problems in the primary environment. Figure 3 shows the risk assessment results of engineering geological problems in the primary environment.The factors affecting major environmental engineering geological issues are primary environmental engineering geological factors and secondary environmental engineering geological factors. Because the primary environmental engineering geological problems and the secondary environmental engineering geological problems are complementary in affecting the major environmental engineering geological problems of Jinan, the Nemerow index method and the analytic hierarchy process are combined to comprehensively evaluate the two secondary indicators.

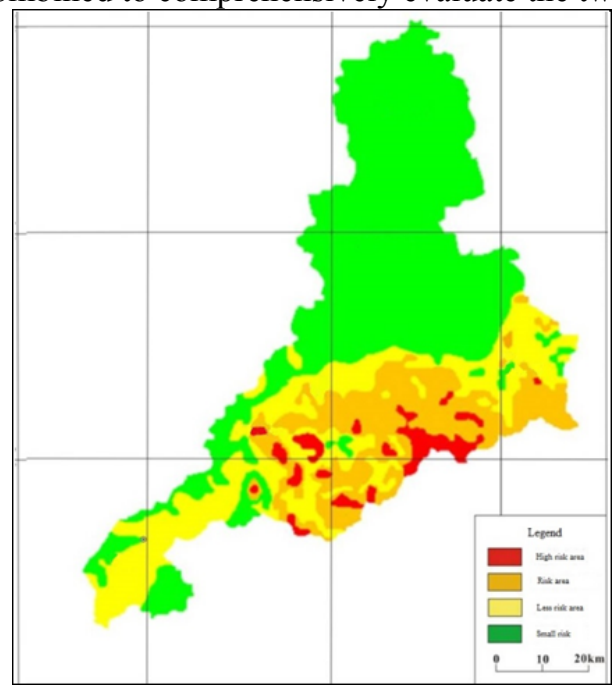

Fig. 2. Risk assessment results of primary environmental engineering geological problems. 


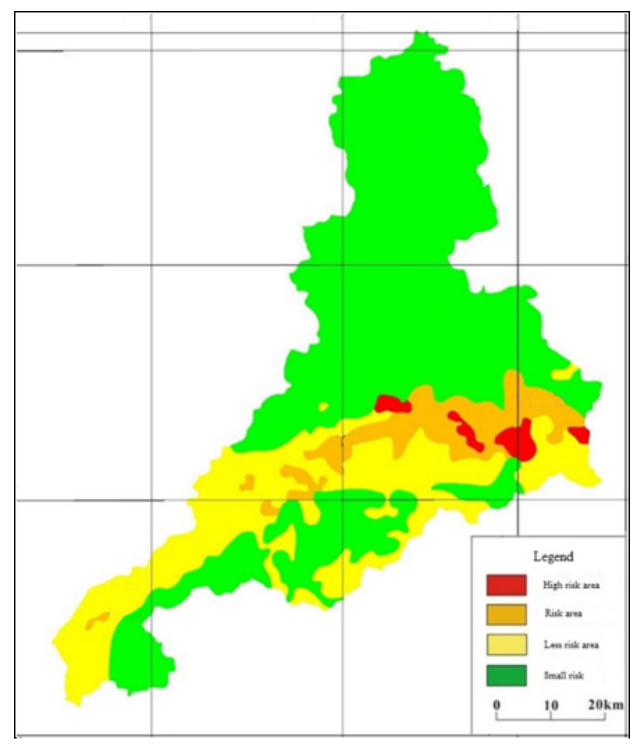

Fig. 3. Risk assessment results of engineering geological problems in secondary environment.

The Nemerow index method was used to calculate the normalized values of primary environmental engineering geological problems index and secondary environmental engineering geological problems index.The primary and secondary environmental engineering geological problems of each grid were calculated according to the formulas. Safety grade and description of major environmental engineering geological indexes are shown in Table 2.

Table 2. Safety grade and description of major environmental engineering geological indexes.

\begin{tabular}{cl}
\hline Security level & \multicolumn{1}{c}{ Level description } \\
\hline $\begin{array}{c}\text { Class A } \\
{[0,2.5]}\end{array}$ & $\begin{array}{l}\text { This level is the lowest safety level and is not suitable for major environmental engineering } \\
\text { construction. Involving primary environmental factors and secondary environmental factors } \\
\text { are inappropriate, human activities are strong, and population density is high. }\end{array}$ \\
$\begin{array}{l}\text { This level is a restricted safety level. When major environmental projects are being } \\
\text { constructed, it is more restricted by primary and secondary environmental factors, and } \\
\text { human activities are relatively strong. }\end{array}$ \\
$\begin{array}{l}\text { This level is a selective security level. During the construction of major environmental } \\
\text { projects, it is less restricted by primary and secondary environmental factors, and the }\end{array}$ \\
$\begin{array}{l}\text { intensity of human activities is medium. } \\
\text { Class D }\end{array}$ & $\begin{array}{l}\text { This level is the highest safety level and is suitable for major environmental engineering } \\
\text { construction. Some areas are affected by a single factor, but the impact is relatively small. }\end{array}$ \\
{$[7.5,10]$} &
\end{tabular}

$$
P_{\mathrm{j}}=\sqrt{\frac{F_{\mathrm{j} \text { max }}^{2}+\left(\overline{\mathrm{F}}_{\mathrm{j}}\right)^{2}}{2}}
$$

Where: $F_{\text {jmax }}$ is the largest single factor environmental quality index.

$\overline{F_{j}}$ is the average value of each single factor environmental quality index.

The evaluation criteria are shown in Table 2. 
The evaluation of the engineering geological problems of the original environment in the grids with $\mathrm{ID}=1394$ and 1395 can be obtained as follows:

$$
X_{\text {native } 1394}=\frac{6.5248-5.0075}{8.6808-5.0075} \times 10=4.1305, \quad X_{\text {native } 1395}=\frac{6.2525-5.0075}{8.6808-5.0075} \times 10=3.3894
$$

The evaluation of engineering geological problems of secondary environment in grids WITH ID=1394 and 1395 can be obtained.

$$
X_{\text {secondary } 1394}=\frac{7.4598-4.1895}{8.7500-4.1895} \times 10=7.1708, \quad X_{\text {secondary } 1395}=\frac{6.2525-4.1895}{8.7500-4.1895} \times 10=7.8303
$$

According to the grading standards, the security level of the grids with ID=1394 and $\mathrm{ID}=1395$ is $\mathrm{C}$. Other grids were graded according to the above evaluation method, and the vector diagram of the comprehensive evaluation zone was obtained, as shown in Figure 3.According to the above figure, the geological safety evaluation of major environmental engineering in Jinan is divided into four grades, namely Grade A, B, C and D.

Table 3. Natural-human environmental engineering geological index calculation table.

\begin{tabular}{cccccc}
\hline Cell & $\begin{array}{c}\text { Area }\left(\mathbf{k m}^{2}\right. \\
\mathbf{n}\end{array}$ & $\begin{array}{c}\text { Perimeter } \\
\mathbf{( k m )}\end{array}$ & $\begin{array}{c}\text { Primary environment } \\
\text { engineering geology } \\
\text { index value }\end{array}$ & $\begin{array}{c}\text { Engineering geological } \\
\text { index of secondary } \\
\text { environment }\end{array}$ & $\begin{array}{c}\text { Nemerow index } \\
\text { method calculated } \\
\text { after the value }\end{array}$ \\
\hline 1394 & 4 & 8 & 4.1305 & 7.1708 & 6.4556 \\
1395 & 4 & 8 & 3.3894 & 7.8303 & 6.8111 \\
\hline
\end{tabular}

The area of Class A security zone is about $398.46 \mathrm{~km}^{2}$, accounting for $4.97 \%$ of the whole city.

The area of Class B security zone is about $1467.52 \mathrm{~km}^{2}$, accounting for $18.30 \%$ of the whole city.

The area of Class C security zone is about $1956.53 \mathrm{~km}^{2}$, accounting for $24.40 \%$ of the whole city.

The area of Grade D security zone is about $4194.80 \mathrm{~km}^{2}$, accounting for $52.32 \%$ of the whole city.

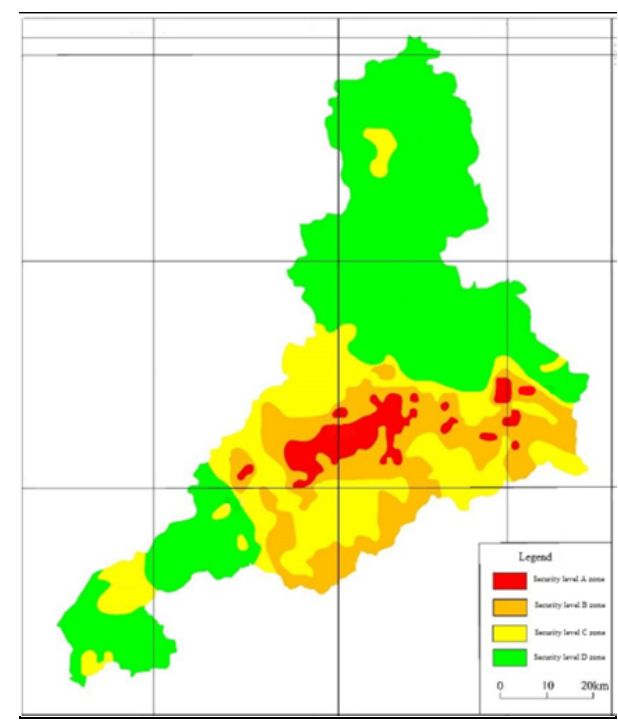

Fig. 4. Safety evaluation results of urban environmental engineering geological problems. 


\section{Conclusions}

Urban environmental engineering geology is the core of environmental engineering geology research. At present, it mainly studies the regional adverse engineering geological effects in urban development, urban geological disasters, seismic, geological problems, geological problems caused by human engineering economic activities, urban water and soil pollution, and heavy metal pollution. The key problems to be solved in urban environmental engineering geology include establishing and improving the database of environmental quality of urban environmental engineering geology and predicting and evaluating the quality of environmental engineering geology in urban three-dimensional space

The nemerow index method is used to comprehensively evaluate the above two problems, and the safety zoning of environmental engineering geological problems in Jinan is obtained. It can be divided into four types: A, B, C and D. The area of grade A safety area is about $398.46 \mathrm{~km}^{2}$, accounting for about $4.97 \%$ of the city's area. The area of grade B safety area is about $1467.52 \mathrm{~km}^{2}$, accounting for $18.30 \%$ of the city's area. The area of grade C safety area is about $1956.53 \mathrm{~km}^{2}$, accounting for $24.40 \%$ of the city's area. The area of grade D safety area is about $4194.80 \mathrm{~km}^{2}$, accounting for about $52.32 \%$ of the city's area. Compared with the original evaluation results, this comprehensive evaluation method of "primary and secondary" environmental engineering geology is more scientific and more consistent with the actual situation.

\section{References}

1. X.C.Ling, L.X. Wang, H. Zhou, J. Some environmental engineering geology problems in urban construction,Harbin Univ. Eng. Architect. 33,30(2000)

2. J.M. Lee, Study on urban engineering geological conditions and geological problems, Eng. Constr. 25,4(2011)

3. C.E. Feng, J.W. Zhou, A.G. Zhou, Chin. J. Current development characteristic and tendency of environmental geology in the world and analysis of environmental geology problems in our country,Geol. Hazard Control 15,9(2004)

4. C.S. Wang,W.M. Ye,H.J. Du, Chin. J. The Urban Geo-Environmental Effect of Underground Engineering in Shanghai City, Undergr. Space Eng. 1,283(2005)

5. G.H. Luo,C.H. Yan, X.Z. Lee,B.T. Xu, J. Study on urbanization and urban environment geotechnical engineering and geological hazard,Eng. Geol. 12,125(2004)

6. Y.J. Chen,C.H. Zhang, Resour. Discussion on key techniques and problems of modern urban environmental engineering geology ,Economization Environ. Prot. (3),51(2015)

7. X.R. Lee,S.H. Zhang, J. Geol. Study on systematic prevention and control of environmental engineering geological problems in coastal cities, Hazards Environ. Preservation 10,20(1999)

8. L.P. Xing, J. Discussion on environmental engineering geology in urban construction,Henan Sci. Technol. (7),174(2014)

9. R.G. Israfilov, Anthropogenic changes to hydrogeological conditions in urban areas,Urban Groundwater Manage. Sustainability 74,11(2006)

10. G.R. Liu, Research on urban environmental engineering Geology .Hydrogeol. Eng. Geol. 4,43(1989) 
11. H.T. Liu, S.C. Gao, Analysis of environmental engineering geology problems in urban construction ,Forest. Sci. Technol. Inform. 41,90(2009)

12. S.Y. Guan, S.D. Pang, Z.G. Long, Review on environmental and engineering geology prombles of Wuhan city,J. Eng. Geol. 15,186(2007)

13. D.B. Wang, S.B. Yan, Discussion on urban environment engineering geology of Qingdao city,J. Eng. Geol. 14,251(2006)

14. G.F. Lee, Problems of environmental engineering geology for city construction and sustainable development of Tangshan .J. Hebei Inst. Technol. 27,121(2005)

15. X.L. Zhao, Exploration of environmental engineering geological problems, Energy and Energy Conservation (04),67(2013)

16. L.P. Xing, Study on the status quo of urban environment and urban engineering geology J. Henan Sci. Technol. (14),174(2014)

17. Y.Q. Jia, Analysis of environmental engineering geology problems in urban construction ,Low Carbon World (9),130(2015)

18. D.D. Zhang, Discussion on key techniques and problems of modern urban environmental engineering geology, Tourism Overview (11),233(2014)

19. S.J. Wang, Geological environment problems in urban development in China J. Quatern. Sci. 02,115(1996)

20. L.J. Yue, Research status and existing problems of geotechnical geology of urban environment,China Homes,2011,(5),146.(2011)

21. Mejía-Navarro Mario, E. Wohl Ellen, Geological hazards vulnerability and risk assessment using GIS:model for Glenwood Spring, Colorado ,D. Oaks Sherry, Geomorph. 10,331(1994)

22. M. Fedeski, J. Gwiliiani, Urban sustainabiiity in the presence of food and geo logical hazards: The development of a GIS-based vulnerability and risk assessment methodology ,Landsc. Urban Plan. 83,50(2007)

23. F. Guzzetti, A. Carrara. M. Cardinali. P. Reichenbach, Landslide hazard evaluation: a review of currentte chniques and their application in amultiscale study. Central Italy, Geomorphology 31,181(1999)

24. M. d Ayman Hassaan Ahmed, E.S. Marwa Adel, Development of sustainable urban green areas in Egyptian new cities :The case of EISadat City, Urban Plan. 101,157(2011)

25. E. Alparslan, F. Ince, B. Erkan, C. Aydöner, H. Özen, A. Dönertaş, S. Ergintav, F.S. Yağsan, A. Zateroğulları, I. Eroğlu, M. Değer, H. Elalmış, M. Özkan, A GIS model for settlement suitability regarding disaster mitigation, a cases tudy in Bolu Turkey ,Eng. Geol. 96,126(2008)

26. L.J. Zhang, Study on urban environment and urban engineering Geology,Sci. Technol. (4),30 (2014)

27. H.W. Lee, The study on urban engineering geological environmental quality in planning, J.W.Xu, J. Eng. Geol. 14,204(2006)

28. J.L. Jia, Systematic engineering analysis method of urban environmental engineering geology and its application,Chin. Acad. Geol. Sci. 1991.

29. D.J. Du, Research route and comprehensive evaluation of urban engineering geological environment, Hydrogeol. Engi. Geol. (5),3(1989)

30. Y.G. Jia, Study on the stability of Qingdao urban geological environment system ,H.J. Liu, Coast. Eng. (03),28(1998) 
31. Y.D. Lu, J. Zhang, M.S. Lee, GIS-based evaluation of urban environmental engineering geology by fuzzy logic: a case study of LuyangCounty, Shaanxi Province,J. Nat. Disaster. 14,93(2005)

32. J.X. Wang, Analysis and evaluation of engineering geological environment quality of Olympic Park, Chin. Univ. Geosci. Beijing 2006.

33. Q. Gao, Study on the theory and method of urban Engineering Geological environmental quality evaluation, Manage. Technol. SME (9),154(2014)

34. X.R. Lee, H.Q. Quan, Z.B. Cao, BP model of neural network theory and its application to urban environmental engineering geology, Environ. Monitor. Chin. 17,15(2001)

35. X.R. Lee,J.Q Guo,X.G. Zong, Study on the theory and method of urban Engineering Geological environmental quality evaluation, J. Ningxia Eng. Technol. 1,35(2002)

36. S.Q. Han, Comprehensive evaluation of engineering geological environment in Shijiazhuang city based on BP neural network ,Hebei Univ. Technol. (2005)

37. Z. Miao, Study on evaluation of Urban geological environment quality in Xi 'an based on GIS, Chang an Univ. (2007)

38. Y.C. Zhang, Engineering geological modeling and environmental quality assessment of the construction layer in Tongzhou District of Beijing ,Chin. Univ. Geosci.,Beijing (2009)

39. X. Huang, Research on engineering geological environment and construction suitability of Beijing Yanqing Planning New Town ,Chin. Univ. Geosci.,Beijing (2013). 